\title{
PHYTOREMEDIATION POTENTIAL OF KENAF (HIBISCUS CANNABINUS) IN SOIL CONTAMINATED WITH USED LUBRICATING OIL Abioye, $0 . P^{l}$ Agamuthu, $P^{l}$ Abdul Aziz, $A^{2}$ \\ ${ }^{1}$ Institute of Biological Sciences, University of Malaya 50603 Kuala Lumpur, Malaysia ${ }^{2}$ Department of Chemical Engineering, University of Malaya 50603 Kuala Lumpur, Malaysia E-mail:bisyem2603@yahoo.com
}

\begin{abstract}
Soil and groundwater contamination incidences with petroleum and petrochemical based products are growing in frequency and quantity. One example is used lubricating oil from machineries. There is a growing demand to remediate the contaminated soil with in-situ phytoremediation. Therefore in this work, Hibiscus cannabinus was investigated for its potential to remove hydrocarbon and heavy metals from soil contaminated with $2.5 \%$ and $1 \%$ used lubricating oil and amended with organic wastes [banana skin (BS), brewery spent grain (BSG) and spent mushroom compost(SMC)] for a period of 90 days. Loss of $86.4 \%$ and $91.8 \%$ used lubricating oil was recorded in soil contaminated with $2.5 \%$ and $1 \%$ oil and amended with organic wastes respectively at the end of 90 days. However, $52.5 \%$ and $58.9 \%$ oil loss was recorded in unamended soil contaminated with $2.5 \%$ and $1 \%$ oil, respectively. The plant did not accumulate hydrocarbon from the soil but shows appreciable accumulation of $\mathrm{Fe}$ and $\mathrm{Zn}$ in the root and stem. $47.0 \mathrm{mg} / \mathrm{kg}$ and $2.37 \mathrm{mg} / \mathrm{kg}$ of Fe accumulated in the root and stem while 1.5 $\mathrm{mg} / \mathrm{kg}$ and $1.64 \mathrm{mg} / \mathrm{kg}$ of $\mathrm{Zn}$ accumulated in roots and stems of $H$. cannabinus respectively at the end of the experiment. The results of this study suggest that $H$. cannabinus has high potential for remediation of hydrocarbon and heavy metal contaminated soil.
\end{abstract}

\section{KEYWORDS}

Phytoremediation, Hibiscus cannabinus, used lubricating oil, soil contamination.

\section{INTRODUCTION}

Soil contamination by used lubricating oil from automobiles is a growing concern in many countries, especially in Asian and African continents [1]. Soil contamination is a problem of global scope, and yet no universal solution has been discovered to deal with it [2]. Different methods have been employed in remediating contaminated soil with each having one form of disadvantages or the other. Phytoremediation of contaminated soil offers an environmentally friendly, cost effective, carbon neutral approach for the cleanup of toxic pollutants in the environment [3]. It appears attractive because in https://doi.org/10.15626/Eco-Tech.2010.087 
contrast to most other remediation technologies, it is not invasive and in principle delivers intact biological active soil [4].

Variety of pollutant attenuation mechanisms possessed by plants makes their use in remediating contaminated land and water more feasible than physical and chemical remediation [5 \& 6]. An estimated 350 species of plants naturally takes up toxic materials from the environment [7].

Different types of plants have been found useful for phytotreatment of soil contaminated by hydrocarbons. Alfalfa and horse radish was found to reduce concentration of kerosene-based jet fuel by $57-90 \%$ in five months [8]. Peng, et al., [9] observed 41.61 - 63.2\% total petroleum hydrocarbons (TPH) removal by Mirabilis jalapa L. in 127 days. Euliss, et al., [10] found out that Carex stricta, Pannicum virgatum and Tripsacum dactyloides significantly reduced TPH by $70 \%$ after one year of growth. Study by Mun et al., [11] shows Hibiscus cannabinus as a potential plant for remediation of heavy metals-contaminated soil.

The choice of Hibiscus cannabinus for this study was because it is a non edible plant and due to its commercial viability as a raw material for paper production. The objectives of the study is to assess the potential of Hibiscus cannabinus in removing hydrocarbons and heavy metals in soil contaminated with used lubricating oil and to investigate the effects of different organic wastes amendments on the ability of Hibiscus cannabinus in removing hydrocarbons from the contaminated soil.

\section{MATERIALS AND METHODS}

\subsection{Sample collection}

The soil with no history of hydrocarbon contamination used for the phytoremediation studies was collected from Nursery section of Asian-European Institute, University of Malaya. The Hibiscus cannabinus seeds were purchased from National Tobacco Board of Malaysia, Kelantan, Malaysia. Used lubricating oil was collected from Perodua car service centre, Petaling Jaya, while organic wastes were collected from different locations; banana skin (BS) was collected from IPS canteen, University of Malaya, brewery spent grains (BSG) was collected from Carlsberg brewery, Shah Alam, Selangor and spent mushroom compost (SMC) was collected from Gano mushroom farm, Tanjung Sepat, Selangor.

\subsection{Physicochemical properties of soil, organic wastes and used lubricating oil}

Nitrogen content of soil used for phytoremediation and organic wastes was determined using the Kjeldahl method; while phosphorus, iron and zinc contents were determined using inductively coupled plasma-optical emission spectroscopy (ICP-OES optima 4100 DV, Perkin Elmer, USA) after acid digestion in a microwave oven. The $\mathrm{pH}$ was determined with $\mathrm{pH}$ meter (HANNA HI 8424) on 1:2.5 (w/v) soil/distilled water after 30 min equilibration. Triplicate determinations were made.

\subsection{Soil preparation}

Four kilogram (4 kg) of sieved $(2 \mathrm{~mm})$ soil each was contaminated with $2.5 \%$ and $1 \%$ $(\mathrm{w} / \mathrm{w})$ of used lubricating oil and thoroughly mixed, 5\% (w/w) of different organic wastes (BS, BSG and SMC) were also mixed separately with the oil contaminated soil. Plastic bags were filled with the soil-oil-organic waste mixture and allowed to stabilize 
for four days before planting the seeds of Hibiscus cannabinus into the contaminated soil. Control treatment consisting of bags of the plant without used lubricating oil or organic wastes was also set up. Additional control treatment comprising of autoclaved soil containing $0.5 \%(\mathrm{w} / \mathrm{w}) \mathrm{NaN}_{3}$ was also set up to determine non-biological loss of waste lubricating oil from the soil. All the treatments were set up in triplicate at the experimental site exposed to sunlight and rainfall for the period of 90 days. The appearance of the plants in response to the oil in soil was monitored to determine if there is phytotoxicity of the oil to the plants. The design of the experiment is as shown in Table 1.

\subsection{Sampling}

Soil samples were taken within the rhizosphere zone of the plant from each plastic bag every 30 days for analysis of total petroleum hydrocarbon (TPH). At the completion of the experiment (90 days), the plants were uprooted. The soil samples were collected from the rhizosphere of each plant and analyzed for residual total petroleum hydrocarbons, heavy metals (Fe, $\mathrm{Zn}$ ) contents and hydrocarbon utilizing bacterial counts. The root was rinsed thoroughly with tap water and the plant dry matter was determined after drying at $60{ }^{0} \mathrm{C}$ for 48 hours. The root tissue was extracted with mixture of hexane and dichloromethane in a Soxhlet extractor for 12 hours to determine if the roots absorb the hydrocarbon from soil. The extracts were analyzed for hydrocarbons using gas chromatography with a mass-selective detector (GC/MSD) HP6890 in scan mode. The GC was equipped with cross-linked 5\% phenyl methyl siloxane capillary column; HP-5MS. Helium was used as carrier gas. The temperature program was started at $40{ }^{\circ} \mathrm{C}$ and raised by $10{ }^{\circ} \mathrm{C} / \mathrm{min}$ until $300{ }^{\circ} \mathrm{C}$, which was maintained for 8 $\min$.

The total extents of used lubricating oil biodegradation in soil were determined by suspending $10 \mathrm{~g}$ of soil (dried with anhydrous sodium sulphate) in $20 \mathrm{~mL}$ of dichloromethane in a $250 \mathrm{~mL}$ capacity Erlenmeyer flask. After shaking for 1 hour on an orbital shaker (Model N-Biotek-101), the solvent-oil mixture was filtered using Whatman number 4 filter paper into a beaker of known weight and the solvent was completely evaporated in a rotary evaporator. The new weight of the beaker (now containing residual oil) was recorded. Percentage biodegradation of used oil was calculated using the formula of Ijah and Ukpe [12]

$\%$ biodegradation $=\frac{\text { weight of oil (control) }- \text { weight of oil (degraded) }}{\text { Weight of oil (control) }} \times \frac{100}{1}$

Statistical analysis of the data was carried out using one - way ANOVA with SPSS Statistics version 17.0. 
Table 1 Experimental Design

\begin{tabular}{ll}
\hline Treatment & \multicolumn{1}{c}{ Details of Treatment } \\
\hline A & $4 \mathrm{~kg}$ soil $+2.5 \%$ oil $+10 \% \mathrm{BS}+$ Hibiscus plant \\
$\mathrm{B}$ & $4 \mathrm{~kg}$ soil $+2.5 \%$ oil $+10 \% \mathrm{BSG}+$ Hibiscus plant \\
$\mathrm{C}$ & $4 \mathrm{~kg}$ soil $+2.5 \%$ oil $+10 \% \mathrm{SMC}+$ Hibiscus plant \\
$\mathrm{D}$ & $4 \mathrm{~kg}$ soil $+2.5 \%$ oil + Hibiscus \\
$\mathrm{E}$ & $4 \mathrm{~kg}$ soil $+2.5 \%$ oil only \\
$\mathrm{F}$ & $4 \mathrm{~kg}$ autoclaved soil $+2.5 \%$ oil $+0.5 \% \mathrm{NaN}_{3}$ \\
$\mathrm{G}$ & $4 \mathrm{~kg}$ soil $+1 \%$ oil $+10 \% \mathrm{BS}+$ Hibiscus plant \\
$\mathrm{H}$ & $4 \mathrm{~kg}$ soil $+1 \%$ oil $+10 \% \mathrm{BSG}+$ Hibiscus plant \\
$\mathrm{I}$ & $4 \mathrm{~kg}$ soil $+1 \%$ oil $+10 \% \mathrm{SMC}+$ Hibiscus plant \\
$\mathrm{J}$ & $4 \mathrm{~kg}$ soil $+1 \%$ oil + Hibiscus plant \\
$\mathrm{K}$ & $4 \mathrm{~kg}$ soil $+1 \%$ oil only \\
$\mathrm{L}$ & $4 \mathrm{~kg}$ autoclaved soil $+1 \%$ oil $+0.5 \% \mathrm{NaN}_{3}$ \\
\hline
\end{tabular}

\section{RESULTS AND DISCUSSION}

\subsection{Physicochemical properties of soil, organic wastes and lubricating oil used for phytoremediation}

The physicochemical properties of soil used lubricating oil and organic wastes used for phytoremediation as shown in Table 2 revealed that the soil had low nitrogen content $(0.6 \%)$, phosphorus content of the soil was $32.1 \mathrm{mg} \mathrm{kg}^{-1}$. Of the organic wastes used, BSG had higher amount of nitrogen $(1.02 \%)$ compared to BS $(0.4 \%)$ and SMC $(0.5 \%)$.

\subsection{Loss of used lubricating oil in soil}

The percentage biodegradation of used lubricating oil in soil contaminated with $2.5 \%$ oil and 1\% oil are shown in Figures 1 and 2. The percentage biodegradation at the end of 90 days in soil contaminated with $2.5 \%$ and $1 \%$ oil ranged from $2.9 \%$ to $86.4 \%$ and $6.5 \%$ to $91.8 \%$ in all the treatments respectively. Contaminated soil treated with BSG as a source of nutrient for Hibiscus recorded the highest loss of oil $(86.4 \%$ and $91.8 \%)$ in $2.5 \%$ and $1 \%$ contaminated soil respectively; while soil treated with SMC only shows $66.1 \%$ and $67.1 \%$ oil loss in $2.5 \%$ and $1 \%$ contaminated soil at the end of 90 days respectively. However, the contaminated soil containing only Hibiscus plant without organic waste amendment recorded $52 \%$ and $58 \%$ oil biodegradation, while control soil without Hibiscus plant recorded $39.8 \%$ and $41.3 \%$ oil loss in $2.5 \%$ and $1 \%$ pollution at the end of 90 days. $11.1 \%$ and $14.1 \%$ oil loss in soil contaminated with $2.5 \%$ and $1 \%$ oil may be due to non-biological factors like evaporation, photodegradation etc. this was recorded in autoclaved soil treated with sodium azide after 90 days. 
Table 2 Physicochemical properties of soil, used lubricating oil and organic wastes used for phytoremediation

\begin{tabular}{lccccc}
\hline \multirow{2}{*}{ Substrate } & \multicolumn{3}{c}{$(\mathrm{mg} / \mathrm{Kg})$} & $\mathrm{N}(\%)$ & $\mathrm{pH}$ \\
\cline { 2 - 5 } Used oil & $\mathrm{Fe}$ & $\mathrm{Zn}$ & $\mathrm{P}$ & - & - \\
Soil (unpolluted) & 76.34 & 56.05 & - & 0.6 & 6.8 \\
BSG & - & 0.02 & 32.1 & 0.6 & 6.7 \\
BS & - & - & 20.6 & 1.0 & 7.0 \\
SMC & - & - & 21.2 & 0.4 & 5.6 \\
Soil+1\% oil & 60.46 & 32.15 & 33.6 & 0.4 & 6.4 \\
Soil+2.5\% oil & 79.43 & 38.32 & 35.3 & 0.5 & 6.6 \\
\hline
\end{tabular}

BSG: Brewery spent grain; BS: Banana skin; SMC: Spent mushroom compost

High percentage loss of oil in soil treated with organic wastes (BSG, BS, and SMC) and Hibiscus might be due to the presence of appreciable quantities of nutrients $(\mathrm{N} \& \mathrm{P})$ in the organic wastes (Table 2) which possibly enhanced the growth of bacteria present at the rhizosphere of the plants. It may also be due to the fact that addition of organic wastes to the contaminated soil before planting of Hibiscus helps to loosen the compactness of the soil making sufficient aeration available for the indigenous bacteria present in the soil, thereby enhancing their biodegradative activities of the oil from the soil. the results is similar to the results obtained in our earlier studies with Jatropha curcas in which contaminated soil treated with BSG and Jatropha recorded $96.6 \%$ oil biodegradation after 180 days [1]. The result is also in agreement with the findings of Palmroth et al., [13] who recorded $60 \%$ loss of diesel fuel in 30 days in dieselcontaminated soil planted with pine tree and amended with NPK fertilizer. Analysis of variance showed that there is no significant difference between the soil treated with BS, $\mathrm{BSG}$ and $\mathrm{SMC}$ at $(\mathrm{P}<0.05)$, however there was a significant difference between the soil treated with different organic wastes plus Hibiscus and soil with only Hibiscus plant. The results revealed that addition of organic wastes into the contaminated soil planted with Hibiscus rapidly enhanced both the growth of Hibiscus cannabinus and biodegradation of oil in the soil. This is in agreement with the findings of Vouillamoz and Milke [14] who observed that compost addition combined with phytoremediation increases the rate of removal of diesel fuel in soil. 


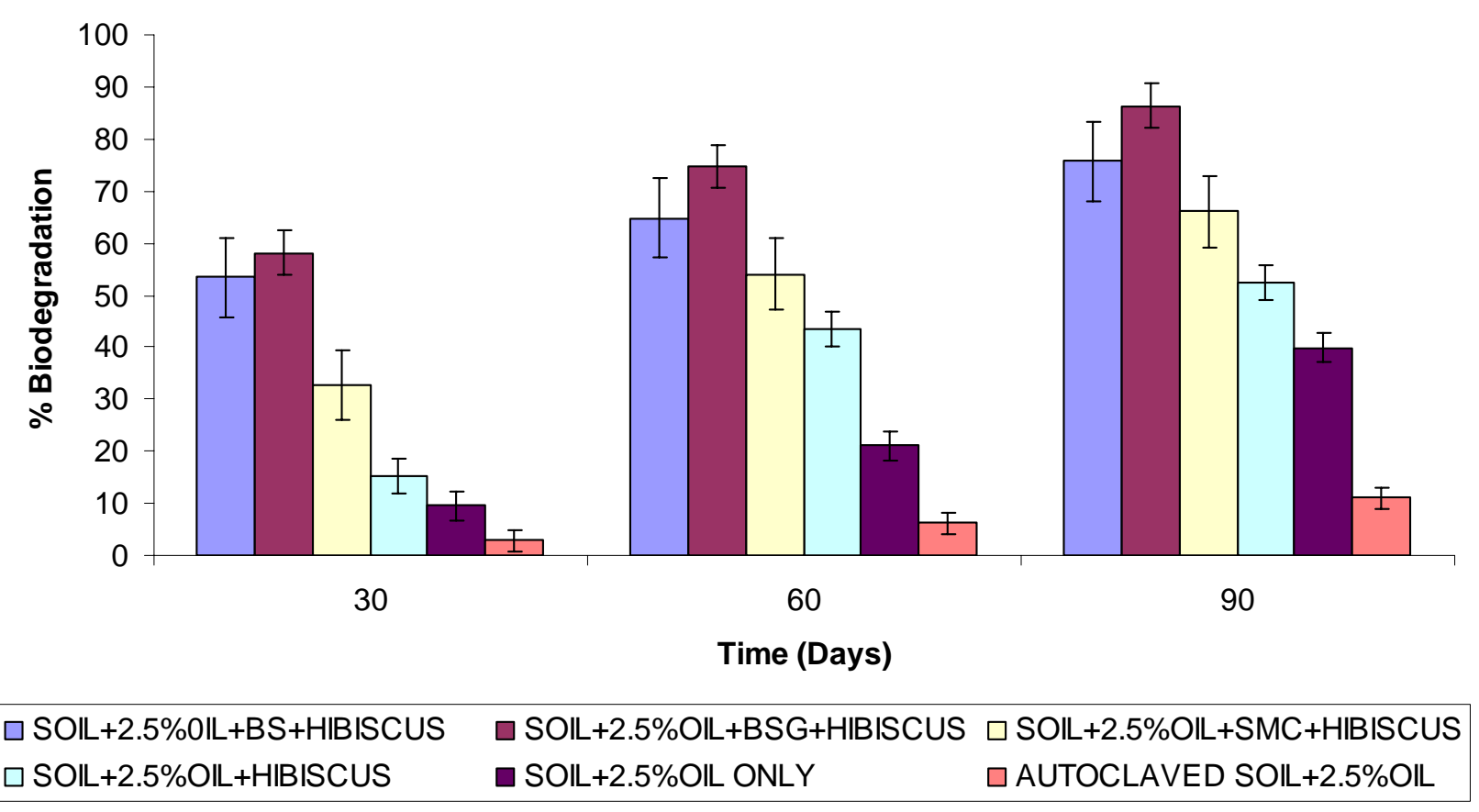

Figure 1. Percentage biodegradation of used lubricating oil in soil contaminated with $2.5 \%$ oil.

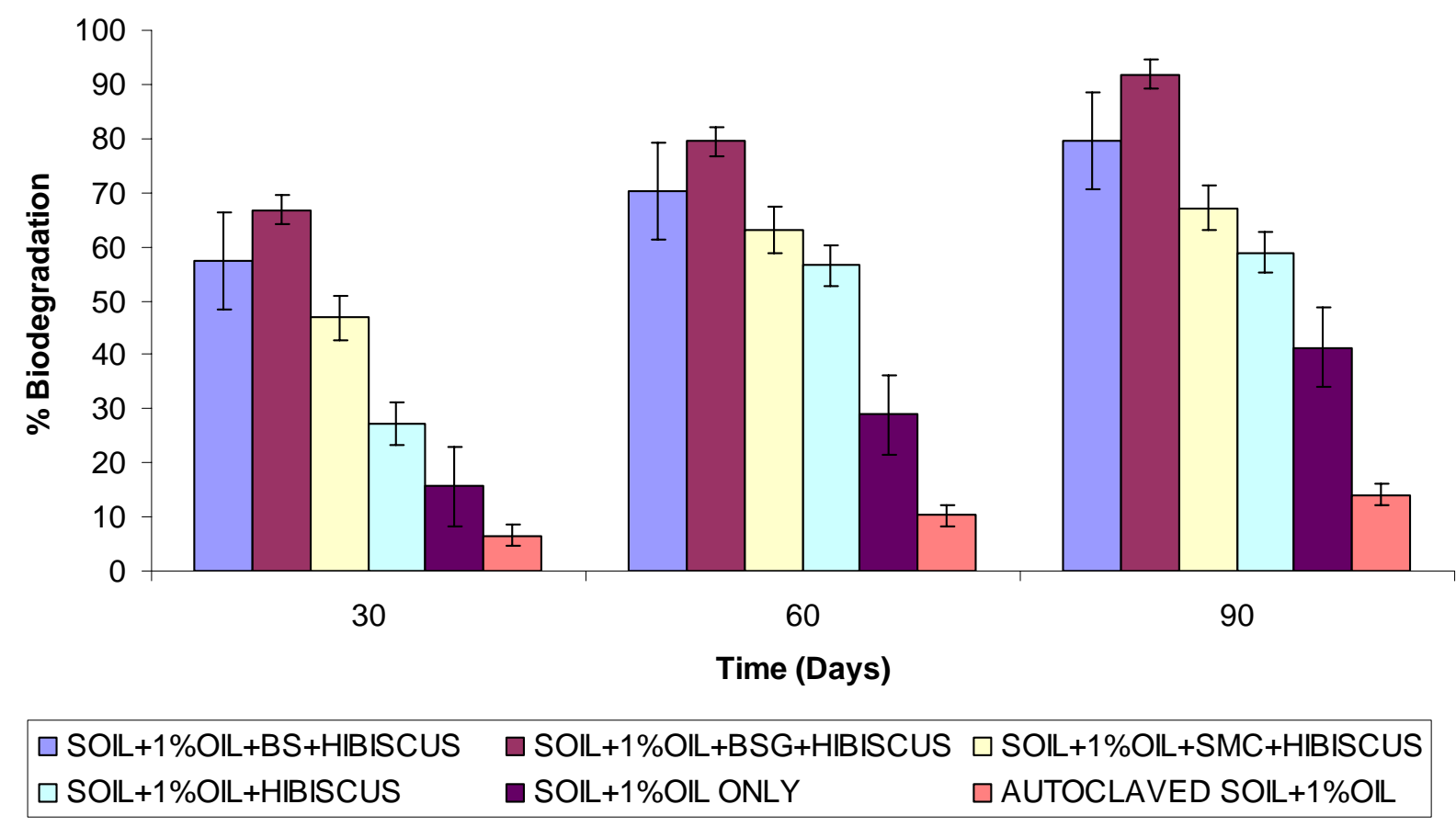

Figure 2. Percentage biodegradation of used lubricating oil in soil contaminated with $1 \%$ oil. 


\subsection{Uptake of oil and metals by Hibiscus cannabinus}

A portion of the Hibiscus roots for different treatment were Soxhlet extracted and analyzed with GC/MS to determine if there was phytoaccumulation of hydrocarbons in the plant root. The results did not show any accumulation of hydrocarbon in the Hibiscus root. This is in sharp contrast with the results of Palmroth et al., [13] who observed uptake of diesel oil by grass roots, but agrees with the findings of Chaineau et al., [15] who did not record uptake of hydrocarbons by maize root. The results suggests that the mechanisms of hydrocarbon removal by Hibiscus cannabinus may be rhizodegradation or by the microorganisms present at the rhizosphere of the plant whose activities might have been enhanced by the added organic wastes or by the root exudates produced by Hibiscus cannabinus.

Another portion of the Hibiscus roots, stems and leaves from different soil treatments were dried at $60{ }^{0} \mathrm{C}$ for 3 days, grounded and digested with mixture of acids were analyzed with ICP-OES to determine if there was accumulation of metals from the oil and soil. The results revealed appreciable accumulation of $\mathrm{Fe}$ and $\mathrm{Zn}$ in the root and stem of Hibiscus, while no metal accumulation was detected in the leaves of all the treatments. Fe accumulation in the root of the plant in soil contaminated with $2.5 \%$ and $1 \%$ used lubricating oil ranged from $12.58 \mathrm{mg} / \mathrm{kg}$ to $47.02 \mathrm{mg} / \mathrm{kg}$ and $10.58 \mathrm{mg} / \mathrm{kg}$ to $38.37 \mathrm{mg} / \mathrm{kg}$ respectively; while Fe accumulation in the stem of Hibiscus cannabinus ranged from $1.26 \mathrm{mg} / \mathrm{kg}$ to $2.37 \mathrm{mg} / \mathrm{kg}$ and $1.16 \mathrm{mg} / \mathrm{kg}$ to $1.46 \mathrm{mg} / \mathrm{kg}$ in $2.5 \%$ and $1 \%$ oil pollution (Tables 3). The results revealed the ability of Hibiscus cannabinus to accumulate $\mathrm{Fe}$ in the root and translocate this metal into the stem of the plant. Accumulation of $\mathrm{Zn}$ in the root of Hibiscus cannabinus ranges from $0.32 \mathrm{mg} / \mathrm{kg}$ to 1.48 $\mathrm{mg} / \mathrm{kg}$ in soil treated with $2.5 \%$ oil and from $0.35 \mathrm{mg} / \mathrm{kg}$ to $0.91 \mathrm{mg} / \mathrm{kg}$ in soil treated with $1 \%$ oil. $\mathrm{Zn}$ concentration in the stem of Hibiscus cannabinus was higher than the accumulation in the root; it ranged from $0.32 \mathrm{mg} / \mathrm{kg}$ to $1.64 \mathrm{mg} / \mathrm{kg}$ in soil contaminated with $2.5 \%$ oil and from $0.27 \mathrm{mg} / \mathrm{kg}$ to $1.43 \mathrm{mg} / \mathrm{kg}$ in soil treated with $1 \%$ oil (Tables 4 ).

Table 3 Heavy metal concentrations in root of Hibiscus cannabinus in soil contaminated with $2.5 \%$ and $1 \%$ oil.

\begin{tabular}{lllll}
\hline & \multicolumn{4}{c}{ Heavy metals $(\mathrm{mg} / \mathrm{Kg})$} \\
\cline { 2 - 5 } Treatment & \multicolumn{2}{c}{$2.5 \%$ oil } & & \multicolumn{1}{c}{$1 \%$ oil } \\
\hline Seil + 2.5\% oil + BS + Hibiscus & 47.02 & 1.00 & 22.67 & 0.35 \\
Soil + 2.5\% oil + BSG + Hibiscus & 12.58 & 1.48 & 10.58 & 0.91 \\
Soil + 2.5\% oil + SMC + Hibiscus & 13.20 & 0.97 & 15.17 & 0.89 \\
Soil + 2.5\% oil + Hibiscus & 16.01 & 0.32 & 38.37 & 0.37 \\
Soil - oil + Hibiscus & 29.87 & ND & 29.87 & ND \\
\hline
\end{tabular}

ND: Not detected 
The results of metal accumulation is similar to the study conducted by Hassinen et al., [16] who reported accumulation of $\mathrm{Zn}$ and $\mathrm{Fe}$ in the root and shoot of hybrid aspen in the first year of planting on a metal contaminated site. Addition of organic wastes to the contaminated soil in addition to planting of Hibiscus cannabinus also promoted better biomass yield as well as better accumulation of $\mathrm{Zn}$ and Fe, this might be due to nutrients in the organic wastes which enhanced the growth of Hibiscus cannabinus with lots of fibrous roots. The results is in line with the findings of Mun et al., [11] who reported higher bioaccumulation of $\mathrm{Pb}$ in the root and stem of Hibiscus cannabinus, in their studies, the authors discovered higher accumulation of $\mathrm{Pb}$ in the root and stem when fertilizer was added to one of the treatment. However, the results was in contrast to that of Santosh et al., [17] who reported that application of dairy sludge to soil contaminated with metal and metalloid significantly reduced the uptake of As, $\mathrm{Cr}$ and $\mathrm{Zn}$ by Jatropha curcas. The differences in the two results might be due to different plant and organic wastes used for the studies or it may be due to different environmental factors.

Table 4 Heavy metal concentrations in stem of Hibiscus cannabinus in soil contaminated with $2.5 \%$ and $1 \%$ oil.

\begin{tabular}{lllll}
\hline & \multicolumn{4}{c}{ Heavy metals $(\mathrm{mg} / \mathrm{Kg})$} \\
\cline { 2 - 5 } Treatment & \multicolumn{2}{c}{$2.5 \%$ oil } & & \multicolumn{2}{c}{$1 \%$ oil } \\
\hline Se & Fe & & Zn \\
\hline Soil + 2.5\% oil + BSG + Hibiscus & 1.63 & 1.64 & 1.16 & 1.43 \\
Soil + 2.5\% oil + SMC + Hibiscus & 2.37 & 0.32 & 1.32 & 0.27 \\
Soil + 2.5\% oil + Hibiscus & 1.45 & 0.53 & 1.46 & 0.37 \\
Soil - oil + Hibiscus & 1.26 & $\mathrm{ND}$ & 1.26 & $\mathrm{ND}$ \\
\hline
\end{tabular}

ND: Not detected

\section{CONCLUSION}

The result of this study demonstrates the potential of Kenaf together with organic amendments to remediate hydrocarbons contaminated soil and bio-accumulate heavy metals (Fe \& $\mathrm{Zn}$ ) from the contaminated soil. The use of Kenaf (an economically viable plant) will therefore serve as an alternative method in removing oil contaminants and metals from soil while at the same time promoting the growth of Kenaf which is highly useful to paper manufacturing industries.

\section{ACKNOWLEDGEMENTS}

The authors would like to acknowledge the support of University of Malaya IPPP Grant PS 244/2008C and FRGS/1/10/SG/UM/01/6. 


\section{REFERENCES}

[1] Agamuthu, P., Abioye, O.P., Abdul Aziz, A., 2010. Phytoremediation of soil contaminated with used lubricating oil using Jatropha curcas. Journal of Hazardous Materials 179: $891 \quad-894$.

[2] Jankaite, A., 2009. Soil remediation from heavy metals using mathematical modelling. Journal of Environmental Engineering and Landscape Management 17(2): $121-129$.

[3] Dowling, D.N., Doty, S.L., 2009. Improving phytoremediation through biotechnology. $\quad$ Current Opinion in Biotechnology 20: 204 - 206.

[4] Wenzel, W. W., 2009. Rhizosphere processes and management in plant-assisted bioremediation (phytoremediation) of soils. Plant Soil 321: 385 - 408.

[5] Greenberg, B.M., 2006. Developmentand field tests of a multi-process phytoremediation system for decontamination of soils. Canadian Reclamation 1: 27 $-29$.

[6] Gerhardt, K.E., Xiao-Dong, H., Glick, B.R. Greenberg, B.M., 2009. Phytoremediation and rhizoremediation of organic soil contaminants: Potential and challenges. Plant Science 176: $20-30$.

[7] Thieman, W.J., Palladino, M.A., 2009. Introduction to biotechnology, $2^{\text {nd }}$ edition. Pearson, New York, pp 209 - 222.

[8] Karthikeyan, R., Davis, L.C., Mankin, K.R., Erickson, L.E., Kulakow, P.A., 1999. Biodegradation of jet fuel (JP-8) in the presence of vegetation. In: Proceedings of the 1999 conference on hazardous waste research, St. Louis, Missouri, May 24 - 27, pp. $243-256$.

[9] Peng, S., Zhou, Q., Cai, Z., Zhang, Z. 2009. Phytoremediationof petroleum contaminated soils by Mirabilis jalapa L. in a greenhouse plot experiment. Journal of Hazardous Materials 168(2-3): 14901496.

[10] Euliss, K., Ho, C., Schwab, A.P., Rock, S., Banks, M.K., 2008. Greenhouse and field assessment of phytoremediation for petroleum contaminants in a riparian zone, Bioresource Technology 99: 1961 - 1971.

[11] Mun, H.W., Hoe, A.L., Koo, L.D., 2008. Assessment of Pb uptake, translocation and immobilization in Kenaf (Hibiscus cannabinus L.) for phytoremediation of sand tailings. Journal of Environmental Sciences 20: 13411347.

[12] Ijah, U.J.J., Ukpe, L.I., 1992. Biodegradation of crude oil by Bacillus strains 28A and 61B isolated from oil spilled soil. Waste Management 12: 55-60.

[13] Palmroth, M.R.T., Pichtel, J., Puhakka, J.A., 2002. Phytoremediation of subarctic soil contaminated with diesel fuel. Bioresource Technology 84: $221-228$.

[14] Vouillamoz, J., Milke, M.W., 2009. Effect of compost in phytoremediation of diesel- contaminated soils, Water Science and Technology. 43(2): 291 - 295.

[15] Chaineau, C.H., Morel, J.L., Oudot, J., 1997. Phytotoxicity and plant uptake of fuel oil hydrocarbons. Journal of Environmental Quality 26: 1478 - 1483.

[16] Hassinen, V., Vallinkoski, V., Issakainen, S., Tervahuata, A., Karenlampi, S., Servomaa, K., 2009. Correlation of foliar MT2b expression with Cd and Zn concentrations in hybrid aspen (Populus tremula $\mathrm{x}$ tremuloides) grown in contaminated soil. Environmental Pollution 157: 922 - 930.

[17] Santosh, K. V., Juwarkar, A. A., Kumar, G. P., Thawale, P. R., Singh, S. K., Chakrabarti, T., 2009. Bioaccumulation and phyto-translocation of arsenic, chromium and zinc by Jatropha curcas L.: Impact of dairy sludge and biofertilizer. Bioresource Technology 100: 4616-4622. 